\title{
Three alien spider species (Araneae: Theridiidae) newly found in Poland
}

\author{
Robert RozWAŁKA ${ }^{1}$, Łukasz DAWIDOWICZ ${ }^{1}$ and Wioletta WAWER ${ }^{2}$ \\ ${ }^{1}$ Department of Zoology, Maria Curie-Sktodowska University, Akademicka 19, 20-033 Lublin, Poland; \\ e-mails: arachnologia@wp.pl; mori666@o2.pl \\ ${ }^{2}$ Museum and Institute of Zoology, PAS, Wilcza 64, 00-679 Warszawa, Poland; \\ e-mail:wawer@miiz.waw.pl
}

\begin{abstract}
Global warming and intensive transport favor the spreading of species. In 2015, three theridiid spider species were found in Poland for the first time: Kochiura aulica, Latrodectus geometricus and Theridion melanostictum. Kochiura auilica was transported in pomegranates from Turkey and T. melanostictum in pomegranates from Chile. One female of Latrodectus geometricus hung, with three egg sacs, on a web in a car imported from the USA (2015), and also in grapes imported from Chile, Morocco and RPA (2017). Effect of non-native spider species in Poland is discussed.
\end{abstract}

Key words: first record, introduced species, identification, Kochiura aulica, Latrodectus geometricus, Theridion melanostictum

\section{INTRODUCTION}

Over the last few decades an increasing number of non-native spider species have been observed in Europe (Nentwig 2015). This increase is favored by international and intercontinental transport (Kobelt \& Nentwig 2008, Rozwałka 2008, Nentwig \& Kobelt 2010, Nentwig 2015) and also by climate change (Kobelt \& Nentwig 2008). Alien species may set up stable populations. For example Uloborus plumipes Lucas, 1846, Nesticella mogera (Yaginuma, 1972) and Hasarius adansoni (Audouin, 1826) are the persistent elements of synanthropic spider communities in Central Europe. In the greenhouses of botanic gardens and farms, in zoological gardens spiders found suitable conditions for the development and establishment of a population (Kielhorn 2009, Rozwałka et al. 2013, 2016, Nentwig et al. 2017). For species that can reproduce parthenogenetically as spiders from Ochyroceratidae or Oonopidae, just one female is enough to inhabit an area (Kielhorn 2008). In Europe, the number of unintentionally introduced spider species may be higher than official data indicates, because many of them are small in size, and thus some of them can be overlooked; moreover, determination of the spider species is rather difficult (Kobelt \& Nentwig 2008). In the present study we provide information about three spider species from Theridiidae noted for the first time in Poland: Kochiura aulica, Latrodectus geometricus and Theridion melanostictum.

\section{MATERIAL AND METHODS}

The specimens were collected by hand during the visit in hypermarkets. The material from the USA was passed by worker of the Zoological Garden in Warsaw. All specimens and egg sacs are stored in 70\% ethanol in collection of R. Rozwałka (Lublin). The main literature used for identification was Levi (1980), Levy (1998), Paquin et al. (2008), Le Peru (2011), Simó et al. (2013), Bodkhe et al. (2015), and Nentwig et al. (2017). Drawings were made by R. Rozwałka. 


\section{RESULTS}

\section{Kochiura aulica (C.L. Koch, 1838)}

(Figs 1 \& 2)

Material: Lublin-Bronowice, Witosa Str. [UTM coordinates: FB 17]; hypermarket, in pomegranates imported from Turkey; 15 Nov 2015; 1 juv. (cult. as adult $\delta$ in January 2015); leg. Ł. Dawidowicz, det. R. Rozwałka.

Distribution: This species was originally described from Madeira (Blackwall, 1862). It occurs in the Cape Verde Island and the Canary Islands, through the Mediterranean countries, up to Azerbaijan (WSC 2017). In Western Europe, it is known from the southern part as well as Great Britain (Harvey et al. 2002), Belgium (Bosmans 2009) and west Germany (Arachnologische Gesellschaft 2017). In Central Europe, sites of $K$. aulica occur in the southern Czech Republic (Buchar \& Růžička 2002) and Hungary (Samu \& Szinetár 1999), and also in Ukraine (Mikhailov 2013, Nentwig et al. 2017). But it was not found in Switzerland, Austria or Slovakia (Nentwig et al. 2017). It lives on citrus orchards and olives, vineyards, dry scrubs, bright forests, moors etc. (Harvey et al. 2002, Pantini et al. 2013, Nentwig et al. 2017). It can be easily moved to the colder regions of Europe with fruits.

\section{Latrodectus geometricus C.L. Koch, 1841}

(Figs 3 \& 4)

Material: Warszawa-Targówek [EC 09]; in a car imported from the USA; Nov 2015; 1 + and 3 egg sacs; leg. unknown, det. R. Rozwałka; Puławy [EB 69]; hypermarket, in grapes imported from Chile; 6 Mar 2017; 1 , and remains of cephalothorax and the legs of $2+9,3$ egg sacs; leg. unknown, det. R. Rozwałka; Lublin-Bronowice Grabskiego Str. [FB 17]; hypermarket, in grapes imported from RPA/Maroko; 10 Mar 2017; remains of 1 egg sac; leg. et det. R. Rozwałka; Lublin-Felin Witosa Str. [FB 17]; hypermarket, in grapes imported from RPA; 17 Mar 2017; remains of 1 egg sac; leg. et det. R. Rozwałka.

The diameter of egg cocoons collected in Warszawa was 8, 9 and $11 \mathrm{~mm}$; collected in Puławy was 6 and $7 \mathrm{~mm}$.

Distribution: Meanwhile a cosmopolitan species, common in warmer regions and originating from South America (Nentwig et al. 2017, WSC 2017). In Europe recorded only in Ireland (Nolan 2012) and Belgium (van Keer 2007, 2011), but as single individuals, accidentally transferred from North America, this does not refer to established populations (van Keer 2007, 2011, Nolan 2012). Due to proximity to Asia Minor and the Middle East (Levy 1998, Bayram et al. 2008), some populations of L. geometricus may occur in south-eastern Europe, e.g. Turkey (Nentwig et al. 2017).

Remarks: This species is characterized by high fertility; during its lifetime it can build an average of 22 egg sacs (Bouillon \& Lekie 1961). It occurs in urban areas, around homes, in parks and garden nurseries and occasionally in garages. Latrodectus geometricus is numerous in some regions, but its bites are rare (Vetter et al. 2012). The venom of L. geometricus causes searing pain at the place of biting, abdominal pain, weakness of the legs and sometimes an increase in body temperature. In addition, children may experience sweating and anxiety (Müller 1993). Due to the high polymorphism in coloration (from yellow to dark brown), $L$. geometricus can be mistaken for the related $L$. mactans. 

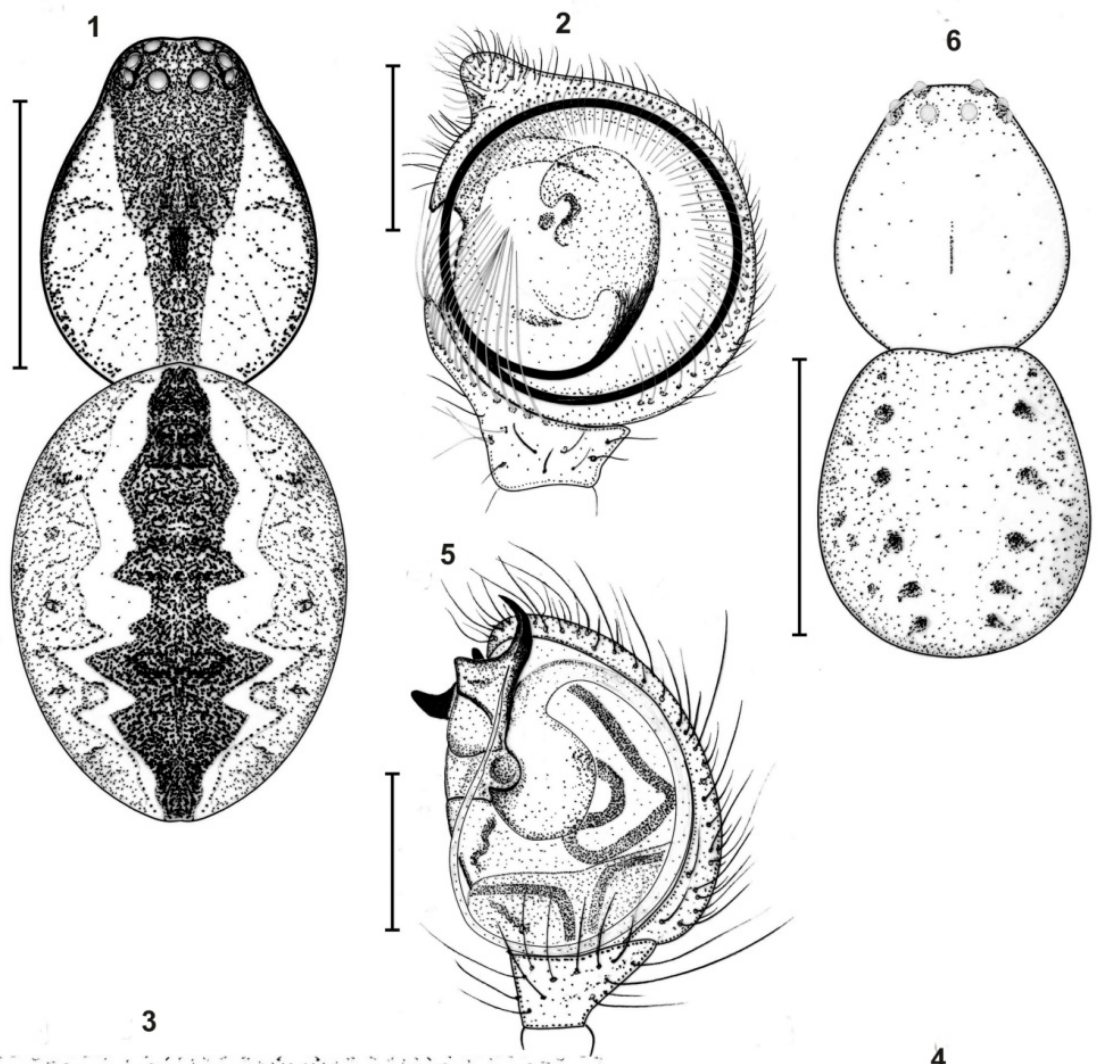

3

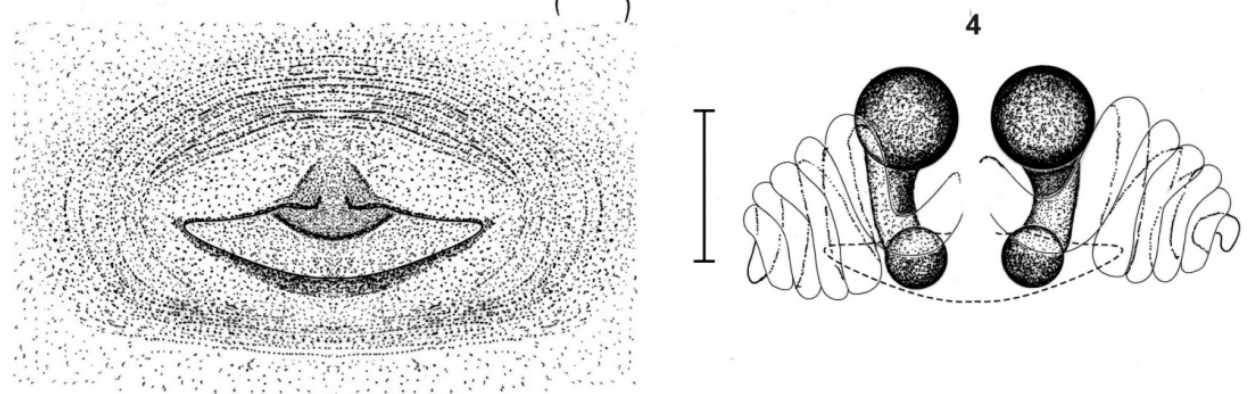

Figs 1-6. Morphological details of Theridiidae found in Poland. Figs 1 \& 2. Kochiura aulica: 1 - male total view, 2 male palp ventral view; Figs 3 \& 4. Latrodectus geometricus: 3 - epigynum, 4 - vulva dorsal view. Figs 4 \& 5 . Theridion melanostictum: 5 - male total view, 6 - male palp lateral view. Scale bars: $1 \& 6=1.0 \mathrm{~mm}$; 2 \& $3-5=0.2$ $\mathrm{mm}$.

\section{Theridion melanostictum O.P.-Cambridge, 1876}

(Figs 5 \& 6)

Material: Lublin-Bronowice Witosa Str. [FB 17]; hypermarket, in pomegranates imported from Chile; 20 Nov 2015; 1 ऊ; leg. Ł. Dawidowicz, det. R. Rozwałka.

Distribution: A rare species, noted in Europe from Spain and Portugal (Le Peru 2011, Nentwig et al. 2017), France (Déjean 2015), Crete and Greece (Bosmans et al. 2013). Outside 
Europe, noted in Canada, Japan, China, India, Egypt and Israel (Levy 1998), and also on Pacific and Indian islands (WSC 2017). It is also known from Haiti (WSC 2017) and the south of the United States (Levi 1980), and from Galapagos (Baert at al. 2016). Theridion melanostictum has not been mentioned from South America mainland so far. It is also probable that collected specimens could have wandered from other fruits originating from the Mediterranean area (Spain, Israel) sold in the vicinity of the Chilean pomegranates. Theridion melanostictum live on woody plants and fruit trees like coconut palms (Howard \& Edwards 1984) and mangrove trees (Dixon \& Anderson 2014).

\section{DISCUSSION}

Among the introduced spider species, most are Theridiidae (Kobelt \& Nentwig 2008). In Poland, exist 66 theridiid species, and three newly arrived species from the Theridiidae family were found over the last decade. These are: Parasteatoda tabulata (Levi, 1980) (Gromov 1997, Rozwałka 2007), Steatoda triangulosa (Walckenaer, 1802) (Rozwałka 2011), both established in the wild, and Latrodectus mactans (Fabricius, 1775) (Rozwałka et al. 2013) not yet established. Generally, unintentionally introduced species can be a threat to human life or health, e.g., Latrodectus mactans (Jäger 2009, Rozwałka et al. 2013) and Phoneutria boliviensis (F. O. Pickard-Cambridge, 1897) (Jäger \& Blick 2009). Species of the genus Latrodectus have highly toxic venom, thus they are considered as one of the most dangerous spiders (Vetter \& Isbister 2008). However, they are rather skittish (Russel et al. 2013), and the bite occurs as an extreme necessity, during accidental contact (Offerman et al. 2011).

Thermophilic species of spiders, dragged to places with a colder climate, in Poland rarely form a stable population in the wild. Usually they live in semi-natural conditions, e.g. greenhouses or plantations (Rozwałka et al. 2013, Pfliegler 2014). Latrodectus geometricus has specific environmental requirements and usually single individuals are transported, thus durable colonization is rather unlikely (Jäger 2009, Rozwałka et al. 2013). In the case of Theridion melanostictum, which lives in Canada in a tropical environment in a theme park (Paquin et al. 2008), settlement in greenhouses or "tropical environments" in Central and Northern Europe is probable, under favorable conditions. In turn, Kochiura aulica lives in natural environments in many parts of Europe; and although it was found in a hypermarket, it is possible that over time this species will settle in natural habitats. But so far, no known viable population of any of the three species mentioned here as new to Poland.

The presence of non-native species may be destructive to an ecosystem (Hänggi \& Straub 2016), but colonization does not always mean a negative impact on the other species (Burger et al. 2001). For Europe, list of alien spider species is long: 184 species were introduced and 51 could establish (Nentwig 2015). So far, no negative effect of non-native spiders has been observed, because most of them live in unnatural conditions (Nentwig \& Kobelt 2010).

\section{REFERENCES}

Arachnologische Gesellschaft 2017. Atlas of the European Arachnids. Version 1.21. Available at http://atlas.arages.de (15 June 2017).

BAert L., VAN KeER J. \& WAUters N. 2016. The spider Theridion melanostictum (Araneae, Theridiidae), a recent introduction to Galapagos? Galapagos Research 68: 13-14.

BAYRAm A., DANiSMAN T., Yigit N., KunT K.B. \& SANKAC A. 2008. A brown widow spider new for the Turkish araneo-fauna: Latrodectus geometricus C. L. Koch, 1841 (Araneae; Theridiidae). Turkish Journal of Arachnology 1: $98-103$

BoDKhe A.K., MANTHEN S.V. \& UniYAL V.P. 2015. First record of Theridion melanostictum O.P.-Cambridge, 1876 (Araneae: Theridiidae) from India. Serket 14: 111-115

Bosmans R. 2009. Een herziene soortenlijst van de Belgische spinnen (Araneae). Nieuwsbrief van de Belgische Arachnologische Vereniging 24: 33-58. 
Bosmans R., van Keer J., Russell-Smith A., Kronestedt T., Alderweireldt M., Bosselaers J. \& DE KoninCK H. 2013. Spiders of Crete (Araneae). A catalogue of all currently known species from the Greek island of Crete. Nieuwsbrief van de Belgische Arachnologische Vereniging 28 (supplement 1): 1-14.

BouILLON A. \& LEKIE R. 1961. Cycle and rhythm in the ovulation of the spider Latrodectus geometricus C. Koch. Nature 191: 620-621. DOI:10.1038/191620a0

BUCHAR J. \& RŮŽIČKA V. 2002. Catalogue of spiders of the Czech Republic. Praha, 351 pp.

Burger J.C., PATTEN M.A., PRENTICE T.R. \& REDAK R.A. 2001. Evidence for spider community resilience to invasion by non-native spiders. Biological Conservation 98: 241-249. DOI: 10.1016/S0006-3207(00)00159-2

DEJEAn S. 2015. Theridion melanostictum O. Pickard-Cambridge, 1876 (Araneae, Theridiidae) nouveau pour la faune de France. Revue Arachnologique 2: 4-5.

DiXON W.N. \& ANDERSON P.J. 2014. Entomology section. Tri-ology 53: 1-12. Available at http://www.freshfromflorida.com/content/download/39194/860979/Triology_May-June_2014.pdf (26 Feb 2016).

Gromov A.V. 1997. New records of spider Achaearanea tabulate Levi (Arachnida: Araneae, Theridiidae) in Palearctics. Izvestiya Ministerstva Nauki Akademii Nauk Respubliki Kazakhstan Seriya Biologicheskaya i Meditsinskaya 1: 31-35.

HÄNGGI A. and STRAUB S. 2016. Storage buildings and greenhouses as stepping stones for non-native, potentially invasive spiders (Araneae) - a baseline study in Basel. Arachnologische Mitteilungen 51: 1-8.

HARVEy P.R., Nellist D.R. \& TelfER M.G. 2002. Provisional atlas of British spiders (Arachnida, Araneae). Volume 1, Biological Records Centre, Centre for Ecology and Hydrology, Abbots Ripton, Huntingdon, 214 pp.

HOWARD F.W. and EDWARDS G.B. 1984. Web-building spiders on coconut palms and they prey (Arachnida; Araneae). Folia Entomológica Mexicana 62: 81-87.

JÄGER P. 2009. Latrodectus mactans nach Deutschland eingeschleppt (Araneae: Theridiidae). Arachnologische Mitteilungen 37: 35-37.

JÄGER P. \& BLICK T. 2009. Zur Identifikation einer nach Deutschland eingeschleppten Kammspinnenart (Araneae: Ctenidae: Phoneutria boliviensis). Arachnologische Mitteilungen 38: 33-36.

KIELHORN K.-H. 2008. A glimpse of the tropics - spiders (Araneae) in the greenhouses of the Botanic Garden BerlinDahlem. Arachnologische Mitteilungen 36: 26-34.

KIELHORN K.-H. 2009. First records of Spermophora kerinci, Nesticella mogera and Pseudanapis aloha on the European Mainland (Araneae: Pholcidae, Nesticidae, Anapidae). Arachnologische Mitteilungen 37: 31-34.

Kobelt M. and NenTwig W. 2008. Alien spider introductions to Europe supported by global trade. Diversity and Distribution 14: 273-280. DOI: 10.1111/j.1472-4642.2007.00426.x

Le Peru B. 2011. The spiders of Europe, a synthesis of data: Volume 1 Atypidae to Theridiidae. Mémoires de la Société Linnéenne de Lyon 2: 1-522.

LEVI H. W. 1980. Two new spiders of the genera Theridion and Achaearanea from North America. Transactions of the American Microscopical Society 99: 334-337. DOI: 10.2307/3226010

LEVy G. 1998. Araneae: Theridiidae. In: Fauna Palaestina, Arachnida III. Israel Academy of Sciences and Humanities, Jerusalem, $228 \mathrm{pp}$.

MikHAilov K. G. 2013. The spiders (Arachnida: Aranei) of Russia and adjacent countries: an non-annotated checklist. Arthropoda Selecta, Supplement 3. 262 pp.

MÜLLER G. J. 1993. Black and brown widow spider bites in South Africa. The South African Medical Journal 83: 399-405.

NENTWIG W. 2015. Introduction, establishment rate, pathways and impact of spiders alien to Europe. Biological Invasions 17: 2757-2778. DOI: 10.1007/s10530-015-0912-5

Nentwig W. \& Kobelt M. 2010. Spiders (Araneae). Chapter 7.3. In: Roques A. et al. (eds), Alien terrestrial arthropods of Europe, pp. 131-147. BioRisk, 4, 570 pp.

Nentwig W., Blick T., Gloor D., HÄNGgi A. \& Kropf C. 2017. Spiders of Europe, version 01.2017. Available at www.araneae.unibe.ch (5 June 2017).

NoLAN M. 2012. A button in a balafon; an occurrence of the widow spider Latrodectus geometricus C. L. Koch (Araneae, Theridiidae) in Ireland. Newsletter of the British Arachnological Society 124: 6-7.

Offerman S.R., Daubert G.P. and Clark R.F. 2011. The treatment of black widow spider envenomation with antivenin Latrodectus mactans: A case series. The Permanente Journal 15: 76-81.

Pantini P., Sassu A. \& SerRa G. 2013. Catalogue of the spiders (Arachnida Araneae) of Sardinia. Biodiversity Journal 4: 3-104.

PAquin P., DuperRe N. \& LABelle S. 2008. Introduced spiders (Arachnida: Araneae) in an artificial ecosystem in eastern Canada. Entomological News 119: 217-226. DPI: 10.3157/0013-872X(2008)119[217:ISAAIA]2.0.CO;2

PfLIEGLER W.P. 2014. Records of some rare and interesting spider (Araneae) species from anthropogenic habitats in Debrecen, Hungary. e-Acta Naturalia Pannonica 7: 143-156.

RozwaŁKa R. 2007. Uwagi o występowaniu Achaearanea tabulata LEVI, 1980 (Araneae: Theridiidae) w Polsce. Nowy Pamiętnik Fizjograficzny 5(2006): 175-186.

RozWAŁKA R. 2008. Skąd pochodzą pająki synantropijne? In: InDYKIEWICZ P., JERZAK L. \& BARCZYK T. (eds), Fauna miast. Ochronić różnorodność biotyczną w miastach, pp. 297-302. Bydgoszcz, 634 pp. 
RozWAlKA R. 2011. Steatoda triangulosa (Walckenaer 1802) (Araneae: Theridiidae) in Poland. Zeszyty Naukowe Uniwersytetu Szczecińskiego, Acta Biologica 18: 143-148.

RozWAŁKa R., RutKOWSKI T. \& BIELAK-BIELECKI P. 2013. New data on introduced and rare synanthropic spider species (Arachnida: Araneae) in Poland. Annales Universitatis Mariae Curie-Sklodowska Lublin, sec. C. 68: 127-150.

Rozwalka R., RutKowSKi T. \& BIELAK-BIELECKI P. 2016. New data on introduced and rare synanthropic spiders (Arachnida: Araneae) in Poland (II). Annales UMCS, sec. C. 71: 59-85.

Russell R.C, Otranto D. \& WALl R.L. 2013. The Encyclopedia of Medical and Veterinary Entomology. University of Sydney, University of Bari, University of Bristol, 440 pp.

SAMU F. \& SzINETÁR C. 1999. Bibliographic check list of the Hungarian spider fauna. Bulletin of the British Arachnological Society 11: 161-184.

Simó M., Dias M.F.R., Jorge C., CAStro M., Dias M.A. \& LABORda Á. 2013. Habitat, redescription and distribution of Latrodectus geometricus in Uruguay (Araneae: Theridiidae). Biota Neotropica 13: 371-375. DOI: 10.1590/S1676-06032013000100040

VAN KEER K. 2007. Exotic spiders (Araneae): Verified reports from Belgium of imported species (1976-2006) and some notes on apparent neozoan invasive species. Nieuwsbrief van de Belgiche Arachnologische Vereniging 22: $45-54$.

VAN KEER K. 2011. Exotische spinnen in België. Een stand van zaken en recente trends. Natuur.focus 10: $96-103$.

VETTER R.S. and IsBister G.K. 2008. Medical aspects of spider bites. Annual Review of Entomology 53: 409-429. DOI: 10.1146/annurev.ento.53.103106.093503

Vetter R.S., Vincent L.S., Danielsen D.W.R., Reinker K.I., Clarke D.E., Itnyre A.A., Kabashima J.N. \& RUST M.K. 2012. The Prevalence of Brown Widow and Black Widow Spiders (Araneae: Theridiidae) in Urban Southern California. Entomological Society of America 49: 947-951. DOI: 10.1603/ME11285

WSC 2017. World Spider Catalog. Natural History Museum Bern, version 18.1. Available at http://wsc.nmbe.ch (15 Jun 2017).

\section{STRESZCZENIE}

\section{[Trzy nowe dla Polski gatunki pająków z rodziny Theridiidae]}

W pracy scharakteryzowano trzy obce, nowe dla fauny Polski gatunki pająków z rodziny Theridiidae. Obecność samic Latrodectus geometricus wraz $\mathrm{z}$ kokonami stwierdzono w samochodzie sprowadzonym z USA, oraz w winogronach importowanych z Chile, Maroka i RPA. W owocach granatów (Punica granatum) odnotowano Kochiura aulica (z Turcji) i Theridion melanostictum (z Chile). Latrodectus geometricus jest gatunkiem często spotykanym w sąsiedztwie człowieka (hemisynantropijnym), w Ameryce Południowej, w cieplejszych rejonach Ameryki Północnej czy w Południowej Afryce skąd sporadycznie bywa zawlekany do Europy Środkowej, a na Bliskim Wschodzie jest już pająkiem zaaklimatyzowanym. Dwa pozostałe gatunki ( $K$. aulica, T. melanostictum) związane są ze środowiskiem naturalnym, gdzie zamieszkują głównie gałęzie drzew i krzewów. Oba gatunki spotykane są w Basenie Morza Śródziemnego, a T. melanostictum także w cieplejszych rejonach obu Ameryk. Pojedyncze przypadki zawleczeń oraz wysokie wymagania termiczne wszystkich w/w gatunków pająków, uniemożliwiają ich trwałą aklimatyzację w środowisku naturalnym w Polsce. Nie można jednak wykluczyć, że w przypadku sprzyjających warunków, mogą wytworzyć trwałe populacje np. w ogrodach botanicznych czy zoologicznych. 